\title{
Complete wastewater discoloration by a novel peroxidase source with promising bioxidative properties
}

\section{Natalia Klanovicz ( $\square$ nataliaklanovicz@gmail.com )}

Research Group in Advanced Oxidation Processes (AdOx), Department of Chemical Engineering, Escola Politécnica, University of São Paulo, São Paulo, Brazil https://orcid.org/0000-0003-0787-7975

\section{Fábio Spitza Stefanski}

Laboratory of Microbiology and Bioprocesses, Federal University of Fronteira Sul, Erechim, Brazil https://orcid.org/0000-0002-2444-2239

\section{Aline Frumi Camargo}

Laboratory of Microbiology and Bioprocesses, Federal University of Fronteira Sul, Erechim, Brazil https://orcid.org/0000-0003-4760-6221

\section{William Michelon}

University of Contestado, Concórdia, Brazil https://orcid.org/0000-0003-0713-0150

\section{Helen Treichel}

Laboratory of Microbiology and Bioprocesses, Federal University of Fronteira Sul, Erechim, Brazil https://orcid.org/0000-0002-3810-3000

\section{Antonio Carlos Silva Costa Teixeira}

Research Group in Advanced Oxidation Processes (AdOx), Department of Chemical Engineering, Escola Politécnica, University of São Paulo, São Paulo, Brazil https://orcid.org/0000-0002-2790-2704

\section{Research Article}

Keywords: Catalytic Processes, Degradation, Downstream, Environmental Biotechnology, Immobilization, Toxicity

Posted Date: January 13th, 2022

DOI: https://doi.org/10.21203/rs.3.rs-846230/v2

License: (c) (i) This work is licensed under a Creative Commons Attribution 4.0 International License. Read Full License

Version of Record: A version of this preprint was published at Journal of Chemical Technology \&amp; Biotechnology on May 16th, 2022. See the published version at https://doi.org/10.1002/jctb.7134. 


\section{Abstract \\ BACKGROUND}

Our study aimed to characterize and prospect immobilization strategies for a novel fungal peroxidase POD (EC 1.11.1.7) and to insert it in the context of pollutant remediation, since these compounds pose risks to human and environmental health. The enzymatic extract was obtained by submerged fermentation of the fungus Trichoderma koningiopsis in an alternative substrate, consisting of fresh microalgal biomass. The immobilization efficiency was evaluated by monitoring the residual activity (RA) and the discoloration potential (DP) of a synthetic dye solution. Concomitantly, the catalytic properties of free POD were explored, and the most promising storage strategy to maintain the enzymatic activity was studied.

\section{RESULTS}

The novel guaiacol peroxidase expressed specific activity of up to $7801 \mathrm{U} \mathrm{mg}^{-1}$ in the free form, showing stability when subjected to up to $80^{\circ} \mathrm{C}$ in a $\mathrm{pH}$ range between 4.0-8.0. Furthermore, the bioproduct immobilized on magnetic nanoparticles expressed up to $689 \%$ RA and $100 \%$ DP. An increase in the RA of the enzyme, both in free and immobilized form, was also observed after storage for up to 8 months. The synthesized magnetic nanozymes showed good reusability, maintaining $13546 \mathrm{U} \mathrm{mg}^{-1}$ after ten cycles and removing $94 \%$ of color in a second batch. Toxicological evaluation with Allium cepa indicated that the enzymatic process of color removal with immobilized POD was essential to eliminate genotoxic effects.

\section{CONCLUSION}

T. koningiopsis peroxidase production and immobilization presented in our work are promising for the enzyme market and for the wastewater treatment technologies, considering its high bioxidative potential.

\section{Introduction}

As part of the subclass of organic chemical compounds known as emerging pollutants, synthetic dyes have been in the environment for a long time. Still, the impacts on human and environmental health have been recognized recently. Their aromatic and highly complex structure makes them resistant to degradation processes and resistant to light and ultraviolet irradiation ${ }^{1}$. Furthermore, it is estimated that the textile industry alone generates around 4500 million kiloliters of wastewater per year ${ }^{2}$, with a significant amount (10-15\%) of the total dyes used by this industry continuously discharged into the environment ${ }^{3}$. 
Since conventional wastewater treatment systems show limited capacity to remediate these contaminants, alternative removal or remediation methods are required. In this context, enzymatic processes arise with catalytic and oxidative properties capable of biotransforming persistent pollutants. These properties put the global enzyme market in constant expansion, with projections of $3.4 \%$ annual growth between 2020-20274, starting to compete with chemical catalysts. Therefore, there is a growing interest in new enzyme sources and low-cost upstream processes, enabling its use as an environmentally and economically viable biocatalyst ${ }^{5}$.

In the wastewater treatment sector, oxidoreductase enzymes laccase - Lac (EC 1.10.3.2) and peroxidase POD (EC 1.11.1.7), mainly obtained from fungi, have been explored for emerging pollutants degradation ${ }^{6,7}$, presenting competitive advantages as performance in mild environmental conditions, low aggressiveness to the environment, and high specificity ${ }^{8}$. However, it is essential to emphasize that there are some challenges considering enzymatic application in contaminants removal, mainly concerning the need to keep the reactions stable and favorable to obtain the maximum catalytic performance.

These challenges can be overcome with noncommercial enzymes, which are highly stable under extreme $\mathrm{pH}$ and temperature conditions and are also economically advantageous. In addition, enzymatic manipulation by immobilization is an exciting strategy to avoid enzymatic denaturation or inhibition and to enhance catalytic action, stability, and reuse by several cycles. Promising results in laccase and peroxidase immobilization results have been reported using organic supports, such as carbon, synthetic polymers, chitosan, sodium alginate, and inorganic supports, such as silica, clay, and metal oxides ${ }^{5,9}$. Different strategies have also been promoting the contact between support and enzymes, such as traditional encapsulation and adsorption, and novel techniques by synthesizing magnetic nanozymes ${ }^{10}$. According to Shakerian, Zhao, and $\mathrm{Li}^{9}$, the principles of these strategies have not changed considerably in recent years, and the focus of immobilization studies remains mainly on prospecting supports and operational parameters.

In this way, the enzymatic immobilization opens interesting perspectives for novel technologies development, both for the enzyme market and the wastewater treatment sector, considering no universal protocols established for these processes ${ }^{11}$. Morsi et al. ${ }^{6}$ emphasize that processes with Lac and POD to remove emerging pollutants from wastewater have been carried out primarily with high-cost commercial enzymes or after their manipulation to increase catalytic efficiency. Therefore, the viability of enzymatic processes for dye remediation also depends on downstream steps to obtain an economically accessible bioproduct, with high catalytic efficiency and possibilities for recovery and reuse.

In this sense, the present study aims to study immobilization strategies of a novel noncommercial peroxidase, obtained through Trichoderma submerged fermentation supplemented exclusively by microalgal biomass, and evaluate its catalytic and toxicological performance in free and immobilized forms for synthetic dye discoloration. 


\section{Materials And Methods}

\section{Enzymatic extract obtention}

The enzymatic extract was produced by a submerged fermentation process using Trichoderma koningiopsis MK860714, supplemented with microalgal biomass, both from noncommercial sources.

The fungus is cultivated by the Laboratory of Microbiology and Bioprocesses, in a partnership with the Laboratory of Agroecology (Federal University of Fronteira Sul, Erechim, Brazil). It was isolated from the weed Digitaria ciliaris, from soybean and corn cultivation areas in southern Brazil ${ }^{12}$.

The Chlorella spp. microalgal biomass was cultivated and kindly provided by Embrapa Swine and Poultry (Concórdia, Brazil). Its cultivation occurs in a biological reactor, aiming at the ammonia and phosphorus removal from swine wastewater digestate by phycoremediation. The biomass is composed of $56 \%$ protein, $35 \%$ carbohydrates, $2 \%$ lipids, and $7 \%$ minerals $^{13}$.

The fermentation was carried out in Erlenmeyer with a practical volume of $100 \mathrm{~mL}$. The medium was composed of $10 \mathrm{~g}$ of fresh microalgal biomass ( $89 \%$ humidity), according to Stefanski et al. ${ }^{14}$. After adding $90 \mathrm{~mL}$ of distilled water to the biomass, the Erlenmeyer was autoclaved at $120^{\circ} \mathrm{C}$ and $1 \mathrm{~atm}$ for $20 \mathrm{~min}$. Then, the medium was inoculated with $10 \mathrm{~mL}$ of a suspension containing $10^{6}$ spores of $T$. koningiopsis per milliliter. The fermentation was conducted for $72 \mathrm{~h}$ in an orbital shaker (New Brunswick $^{\mathrm{TM}}$, Germany) at $120 \mathrm{rpm}$ and $28^{\circ} \mathrm{C}$.

After fermentation, the Erlenmeyer content was filtered to remove the fungal and microalgal biomass, and the liquid permeate was centrifuged (NT 815 - NovaTecnica, Brazil) at $2000 \mathrm{rpm}$ and $4{ }^{\circ} \mathrm{C}$ for $10 \mathrm{~min}$. The supernatant corresponds to the enzymatic extract, and the rest of the fermentation content was sterilized and discarded.

\section{Enzymatic activity quantification}

The quantified oxidoreductases enzymes were guaiacol peroxidase, with methodology adapted from Garda-Buffon et al. ${ }^{15}$, and laccase, adapted from Hou et al. ${ }^{16}$.

For peroxidase, $1 \mathrm{~mL}$ of extract was mixed with $1.5 \mathrm{~mL}$ of sodium phosphate buffer $\mathrm{pH} 5.5\left(5 \mathrm{mmol} \mathrm{L}{ }^{-1}\right)$, $0.5 \mathrm{~mL}$ of the substrate guaiacol $\left(93 \mathrm{mmol} \mathrm{L}^{-1}\right), 1 \mathrm{~mL}$ of the cosubstrate hydrogen peroxide $\left(75 \mathrm{mmol} \mathrm{L}^{-}\right.$ ${ }^{1}$ ), and $2 \mathrm{~mL}$ of distilled water.

The $\mathrm{U}$ unit of peroxidase specific activity was defined as the enzyme amount capable of causing 0.001 increase in the absorbance unit per minute per milligram of total protein, when incubated at $25^{\circ} \mathrm{C}$ for 10 min, and read in a spectrophotometer (UV-M51-Bel, Italy) at $470 \mathrm{~nm}$. Total protein concentration was quantified by Bradford method ${ }^{17}$, and specific activity was expressed in $\mathrm{U} \mathrm{mg}^{-1}$, dividing the enzymatic activity $\left(\mathrm{U} \mathrm{mL}^{-1}\right)$ by the protein concentration $\left(\mathrm{mg} \mathrm{mL}^{-1}\right)$ of the sample. 
For laccase, $0.2 \mathrm{~mL}$ of extract were added to the reaction medium containing $0.4 \mathrm{~mL}$ of 2,2'-azino-di-(3ethylbenzothialozin-6-sulfonic acid) (ABTS) $10 \mathrm{mmol} \mathrm{L}^{-1}$ and $3.4 \mathrm{~mL}$ of sodium acetate buffer $\mathrm{pH} 4.8$ (50

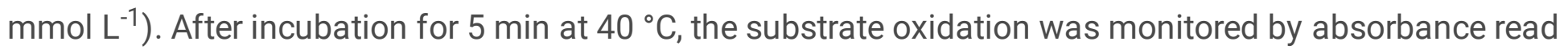
in a spectrophotometer at $420 \mathrm{~nm}\left(\square_{420}=36000 \mathrm{~L} \mathrm{~mol}^{-1} \mathrm{~cm}^{-1}\right)$. The $U$ unit of laccase was defined as the enzyme amount capable of oxidizing $1 \mu \mathrm{mol}$ of substrate per minute.

\section{Discoloration studies}

Preliminary discoloration studies were carried out with four commercial synthetic dyes (Guarany Ind. Ltda., Brazil) to verify the affinity between enzyme and dye and the relationship between enzymatic activity and discoloration potential (DP).

The dyes studied were red ( $455 \mathrm{~nm})$, blue $(595 \mathrm{~nm})$, yellow $(414 \mathrm{~nm})$, and brown $(530 \mathrm{~nm})$. The tests were conducted according to previous studies ${ }^{18}$. The dye solution, prepared with distilled water at $100 \mathrm{mg} \mathrm{L}^{-1}$, was treated with 5 or $10 \mathrm{~mL}$ of crude enzymatic extract and $40 \mathrm{mg} \mathrm{L}^{-1}$ of hydrogen peroxide $35 \% \mathrm{v} \mathrm{v}^{-1}$.

Crude extracts with different peroxidase:laccase ratio, obtained in previous studies ${ }^{14}$ varying operational parameters in fermentation, were applied to the dye removal study. The tests were carried out at a volume of $100 \mathrm{~mL}$ under constant agitation $(160 \mathrm{rpm})$ and temperature $\left(25^{\circ} \mathrm{C}\right)$ for $5 \mathrm{~h}$. The DP was quantified by the difference between initial $\left(A b s_{i}\right)$ and final $\left(A b s_{f}\right)$ absorbances of the treated samples (Equation 1$)$.

$$
D P(\%)=\frac{A b s_{i}-A b s_{f}}{A B S_{i}} * 100
$$

\section{Investigation of the peroxidase activity behavior}

Initially, the reaction conditions and the substrate:enzyme ratio influence in enzymatic activity were evaluated. The effect of substrate $(0.5-1.0 \mathrm{~mL})$ and cosubstrate $(0.5-1.0 \mathrm{~mL})$ concentrations in the reaction medium, and the impact of $\mathrm{pH}(4.0-8.0)$ and incubation temperature $\left(20-80{ }^{\circ} \mathrm{C}\right)$ were studied by the Plackett-Burman experimental design, conducted with 8 trials and 3 replicates under central point conditions.

Then, setting the conditions in the most favorable trial of the design, the behavior of specific activity, $\mathrm{pH}$, and oxidation-reduction potential (ORP) were monitored over time to understand the catalytic cycle of the peroxidase oxidation reaction.

In addition, crude extract samples were stored, protected from direct sunlight, in three different conditions: at room temperature (ranging between $18-28^{\circ} \mathrm{C}$ ), in refrigerator $\left(4^{\circ} \mathrm{C}\right)$, and in freezer $\left(-10^{\circ} \mathrm{C}\right)$. The monitoring of residual activity (RA) was carried out in $15,30,60,90$, and 170 days and calculated by Equation 2, in which $S A_{i}$ and $S A_{f}$ correspond to the pre- and post-storage specific activity, respectively. 


$$
R A(\%)=\frac{S A_{f}}{S A_{i}} * 100
$$

\section{Prospection techniques for enzymatic immobilization}

The $T$. koningiopsis enzymatic extract was submitted to three different immobilization strategies (Table 1 ), and their efficiency was measured by residual activity and discoloration potential.

[Table 1 near here]

The RA was calculated by Equation 2 but, in this case, $S A_{i}$ and $S A_{f}$ respectively correspond to the specific activity of free and immobilized peroxidase. Both contents retained in the immobilization supports and the permeate were subjected to enzymatic quantification.

Preliminary tests were conducted to monitor immobilized enzyme activity after storage at room temperature. In addition, the recovery and reuse potential of MN-POD was first assessed in two ways: by activity after 10 catalytic cycles, renewing the peroxidase reaction medium described in Section 'Investigation of the peroxidase activity behavior'; and by a new decolorization batch, according to the procedure detailed in Section 'Discoloration studies'. The MN-POD recovery was made by the commercial magnet NdFeB (N45).

\section{Encapsulation in Ca-alginate beads}

The immobilization in beads was tested in two ways: in the presence and absence of the enzymesubstrate and cosubstrate. In both cases, the methodology was adapted from Rezvani et al. ${ }^{19}$, according to which, initially, a gel was prepared with sodium alginate and distilled water $\left(1.75 \% \mathrm{~W} \mathrm{v}^{-1}\right)$. In this step, the addition of $0.08 \%$ hydrogen peroxide and $1 \%$ guaiacol to the gel was tested, both in a proportion corresponding to the reaction medium of the enzymatic activity measurement.

The enzymatic extract was then added to the gel $\left(6.7 \% \mathrm{v} \mathrm{v}^{-1}\right)$. After homogenization, it was dripped with a peristaltic pump $\left(20 \mathrm{~mL} \mathrm{~min}^{-1}\right)$ to $100 \mathrm{~mL}$ of a calcium chloride solution $\left(4.5 \% \mathrm{w} \mathrm{v}^{-1}\right)$, and kept in an ice bath under constant magnetic stirring.

The beads formed in the previous procedure were kept immersed in the calcium chloride solution for 20 min at $4{ }^{\circ} \mathrm{C}$. Then, a sieve was used to retain the beads, which were then thoroughly washed with distilled water, thus obtaining the POD- and ModPOD-beads samples.

\section{Adsorption on inorganic supports}

The physical adsorption process was tested on two supports: K10-montmorillonite (Lot \#STBH6207, Sigma-Aldrich, Merck, Brazil) and ornamental rock dust (donated from a local rock beneficiation process 
in Rio Grande do Sul, Brazil).

The ornamental rock is the acid volcanic rock rhyodacites, from the Província Paraná Fácies Caxias formation (K1acx), composed with at least $50 \%$ of $\mathrm{SiO}_{2}$ and several oxides. It arrived in the form of sludge ( $0.9 \%$ humidity) and went through an autoclave sterilization process (20 min, 1 atm, $\left.120^{\circ} \mathrm{C}\right)$, drying $\left(2 \mathrm{~h}, 550^{\circ} \mathrm{C}\right)$, and grinding before the immobilization process.

For both supports, the contact with enzymatic extract occurred under magnetic stirring in an ice bath for 10 min, following a methodology adapted from Coghetto et al. ${ }^{20}$. Initially, $2 \mathrm{~g}$ of support was homogenized with $60 \mathrm{~mL}$ of sodium phosphate buffer $5 \mathrm{mmol} \mathrm{L}^{-1}$ and $\mathrm{pH} 5.5$. Then, the enzymatic extract was added at 3:10 $\mathrm{v} \mathrm{v}^{-1}$ enzyme:buffer.

The suspension obtained from this procedure was vacuum-filtered to remove the liquid portion and kept in a desiccator over $48 \mathrm{~h}$ for complete drying. The MK10-POD and OR-POD samples were obtained after grinding the content retained in the filtration procedure.

\section{Magnetic nanozymes synthesis}

The methodology for magnetic nanozymes synthesis was adapted from Sadaf et al. ${ }^{21}$, in which initially a solution composed of $80 \mathrm{~mL}$ of distilled water, $12 \mathrm{~g}$ of urea, and $8 \mathrm{~g}$ of $\mathrm{NaOH}$ was prepared. Under constant stirring at room temperature, the enzymatic extract was added at $3 \% \mathrm{v} \mathrm{v}^{-1}$, and the solution was kept under stirring for $15 \mathrm{~min}$. The enzymatic solution was kept over $12 \mathrm{~h}$ in a refrigerator $\left(4^{\circ} \mathrm{C}\right)$. Then, $100 \mathrm{~mL}$ of $\mathrm{FeCl}_{3} / \mathrm{FeSO}_{4}$ (molar ratio 2:1) solution was added to the enzymatic solution under stirring and $60^{\circ} \mathrm{C}$.

The nanozymes suspension was filtered, washed with distilled water, and then with 95\% ethanol. The retained nanozymes film was dried at $70{ }^{\circ} \mathrm{C}$ for $2 \mathrm{~h}$ and kept in a desiccator over $24 \mathrm{~h}$. The NM-POD sample was obtained after grinding the content retained in the filter.

\section{Toxicological assessment of enzymatic treatment}

The cytotoxicity and genotoxicity study of the dye solution before and after the enzymatic treatment, with free and immobilized peroxidase, was carried out with the organism Allium cepa according to the method described by Fiskesjö ${ }^{22}$.

Onion bulbs purchased in a local market were placed in water to germinate over $72 \mathrm{~h}$, protected from direct sunlight. After root growth, they were exposed in duplicate to the treatments (pure or diluted in distilled water at a 1:8 ratio) for $48 \mathrm{~h}$ at room temperature, maintaining a negative control exposed to tap water. The exposed roots were hydrolyzed in $\mathrm{HCl}$ at $1 \mathrm{~mol} \mathrm{~L}^{-1}$ for 10 min at $60{ }^{\circ} \mathrm{C}$, and then the slides with the meristematic cells of $A$. cepa were prepared. This preparation is necessary for microscope analysis, and the cells were thus stained using the Panótico Rápido ${ }^{\circledR}$ kit (Laborclin). 
Genotoxic effects were observed qualitatively using the Olympus CX21 Biological Microscope, in which changes, such as micronuclei, binucleate cells, and nuclear buds, were considered. The cytotoxic effects were quantified through mitotic changes, considering the different phases of cell division (metaphase, anaphase, and telophase). The mitotic index (MI) was calculated as the ratio between the number of cells observed in any of the division phases (NDC) and the total number of cells analyzed (NTC), according to Equation 3, with a count of up to 100 cells per slide.

$$
M I(\%)=\frac{N D C}{N T C} * 100
$$

\section{Analytical procedures}

Structural analyses of support and immobilized peroxidase were performed by the Nuclear and Energy Research Institute (IPEN/CNEN-SP, Brazil), namely infrared spectrometry (FTIR), using Nicolet 6700 equipment (Thermo Scientific); and X-ray diffraction (XRD), using a Bruker D8 Advance $3 \mathrm{~kW}$ diffractometer, equipped with a $\mathrm{Cu}-\mathrm{K}$ alpha radiation tube and scintillation detector, reading samples at $2 \theta$ angle ranging from 20 to 90 degrees with an increment of $0.05^{\circ}$. Crystalline phases in the XRD analysis were identified by comparing the sample diffractogram with the International Centre for Diffraction Data (ICDD) using X'Pert HighScore Plus software.

ORP and $\mathrm{pH}$ measurements were performed by $\mathrm{pH} / \mathrm{mV}$ bench meter from HANNA Instruments HI2221. Using a silver chloride reference electrode, we quantified the oxidation potential of peroxidase according to Skoog et al. ${ }^{23}$. The values obtained were converted to $\mathrm{mV} v s$. SHE, the standard unit of this electrochemical quantity 24 .

\section{Statistical analysis}

The data from the tests underwent analysis of variance (ANOVA), using the software Statistica 8.0 and the online software Protimiza Experimental Design - http://experimental-design.protimiza.com.br/25.

\section{Results And Discussion}

\section{Relationship between enzymatic activity and discoloration potential}

Preliminary tests with four synthetic dyes were carried out in the present work, aiming to find the affinity between $T$. koningiopsis peroxidase and the structure of the dyes, expecting enzymes to use it as a substrate in the enzymatic bioxidative reaction. Table 2 shows the results.

[Table 2 near here] 
The most significant discoloration percentage occurred for the brown dye (54\%), with statistical significance, comparing the enzymatic extract amount used (3833 or $7667 \mathrm{U}$ ) and the four types of dyes. There was no statistically relevant difference for the red and yellow dyes, but for the blue dye, the enzymatic treatment with $7667 \mathrm{U}$ showed a statistically adequate color removal (22\%).

The different discoloration potential observed between dyes indicates the effect of structural diversity. Each dye has a specific molecular structure, which conveys the characteristics of color and dyeing. Considering the molecular aspect, the relationship between the structure and the enzymatic action depends on the type, number, and position (ortho or para) of the groups linked to the aromatic ring of the dyes. In this sense, the molecular aspect can accelerate, delay, or even cause complete inhibition of the enzymatic action ${ }^{26}$.

Due to its oxidative nature, there are several areas in which peroxidase could replace current techniques based on chemical catalysis ${ }^{27}$. Although different peroxidases have already been extensively studied, most studies use commercial and high-cost enzymes, making environmental applications unfeasible. In this study, the crude enzymatic extract showed specificity for brown dye discoloration. This result is promising since studies that used peroxidases have reported affinity with other dyes. For example, peroxidase extracted from industrial soybean residues was efficient in degrading blue dye after 3.3 hours of reaction ( $70 \%$ degradation $)^{28}$, and peroxidase from macrophytes performed well in the degradation of direct azo dyes, such as amaranth and black starch (93\% and $87 \%$, respectively, after 120 hours of reaction) ${ }^{29}$. Also, for the blue dye, two peroxidase sources (Ipomea palmata and Saccharum spontaneum) showed removals of $15 \%$ and $70 \%$, respectively, after 1 to 2 hours of treatment, indicating different specificities of plant peroxidase to the same dy $\mathrm{e}^{30}$. Enzymatic treatments conducted in other reactional systems also provided different color removal results, as shown by a previous study ${ }^{18}$, in which rice bran peroxidase removed $39 \%$ of the color after 3 hours of reaction in a microwave system, while complete removal was achieved after $24 \mathrm{~h}$ in an orbital shaker.

We verified the relationship between peroxidase and laccase activity with color removal in this study. For this purpose, crude extracts with different enzymatic activity profiles were applied to the brown dye discoloration process. In this experiment, the most remarkable discoloration (32\%), statistically different from the other assays, occurred with enzymatic activities of $350 \mathrm{U} \mathrm{mL}^{-1}$ and $0.03 \mathrm{U} \mathrm{mL}^{-1}$ for peroxidase and laccase, respectively. Even so, these activities did not represent the most considerable enzymatic amount among the 17 assays performed. The maximum and statistically relevant peroxidase activity was $826 \mathrm{U} \mathrm{mL}^{-1}$, in which the color removal was $7 \%$. For laccase, the maximum value was $0.07 \mathrm{U} \mathrm{mL}^{-1}$, and there was only $8 \%$ dye discoloration.

For both peroxidase and laccase, a statistically different enzymatic activity between the assays was observed, which can be explained by the wide range of operational conditions in the fermentation process for the crude extracts production, such as temperature, $\mathrm{pH}$, and agitation. Thus, the fermentation manipulation can provide an enzymatic pool with different performances in application processes, although the maximum activity did not represent the maximum discoloration potential. 
Similar findings were observed when manganese peroxidase $(\mathrm{MnP})$ and manganese independent (MIP) activities were evaluated ${ }^{31}$. The authors found a difference between the enzymatic activity and the discoloration of synthetic sulfonephthalein dyes. The variations in the discoloration reflect the differences in the isoenzyme composition of the MnP and MIP, resulting in a difference in the kinetic constants (varying the maximum rate of reaction from 0.057 to $1 \mathrm{U} \mathrm{mL}^{-1}$ ) and the substrate specificity ${ }^{31}$. Another study also concluded that the reaction conducted with laccase alone did not degrade certain types of dyes. When the redox mediator violuric acid was added, however, the degradation efficiency reached $90 \%$ using $2 / 5$ of the enzymatic activity of the tests without mediator ${ }^{32}$.

Our results thus indicate that the change in operational parameters in fungal fermentation, in addition to providing enzymatic activity variations, must have influenced the composition of isoenzymes. In turn, it caused differences in specificity and interfered with the decolorization activity. It is noteworthy that until this step of the work, no enzymatic manipulation method had been employed. Later on, the reactions with immobilized peroxidase on different supports will be discussed.

\section{Catalytic properties of free and crude peroxidase}

To insert a novel enzyme source in biotechnological processes, it is essential to know and to improve its catalytic properties and reactional conditions. This work is the first to present the preliminary characterization of guaiacol peroxidase produced by $T$. koningiopsis in submerged fermentation supplemented exclusively by fresh microalgal biomass.

The extracellular enzymes of this fungus are rarely mentioned in the literature due to the difficulty in offering favorable conditions for fermentation and supplementation for its expression, often involving costly processes for industrial applications ${ }^{5}$. Mäkelä et al. ${ }^{33}$ report a wide variety of fungal peroxidases being applied as biocatalysts to reactions of environmental interest. In their study, the species Trichoderma is classified as Soft-Rot Fungi, about which little is known concerning peroxidase production. Azmi et al. ${ }^{34}$ reported a combination of lignin peroxidase production in a more significant proportion and manganese peroxidase in a smaller proportion by $T$. koningiopsis when supplemented with oil palm fronds in solid-state fermentation.

Regardless of the peroxidase source, enzymatic processes are influenced by reaction thermodynamics and need studies varying $\mathrm{pH}$, temperature, and availability of substrate and cosubstrate - relevant factors in understanding the catalytic route ${ }^{35}$. In this sense, these variables were investigated in the present work for the $T$. koningiopsis POD following a Plackett-Burman design. The results indicated enzyme stability even when subjected to adverse reaction conditions.

When subjected to $\mathrm{pH}$ ranging from $4.0-8.0$ and temperatures from $20-80^{\circ} \mathrm{C}$, the enzymatic activity was not significantly affected at $95 \%$ confidence level by the Tukey test. The enzyme:substrate and enzyme:cosubstrate ratios, conversely, negatively affected the enzymatic response with statistical relevance; that is, the POD activity was improved at the minimum levels studied. None of the reaction 
conditions led to enzyme denaturation, with the lowest activity obtained being $5733 \mathrm{U} \mathrm{mg}^{-1}$ in a test with $\mathrm{pH} 4.0$, temperature $20^{\circ} \mathrm{C}$, and maximum levels of substrate and cosubstrate.

The peroxidase stability under varying conditions can be explained by the defense mechanisms previously developed by the fungus in its natural habitat ${ }^{36}$. Our enzyme was isolated from weeds already adapted to its ecosystem. The supplementation of the fermentation medium with microalgae biomass induced higher peroxidase productivity compared to synthetic supplementation ${ }^{37}$, confirming that stress induction during the fungus growth improves peroxidase production.

In contrast to the production behavior of other enzymes, stressful environments induce higher productivity of oxidoreductase enzymes and, consequently, fermentation conditions with less nutrient availability can result in greater peroxidase expression. As well as the fungus fermentation process, the microalgae growth process occurred in a stressful environment, considering that it was cultivated with mainly ammonia and phosphorus availability ${ }^{13}$. Thus, according to a previous study ${ }^{14}$, synergism between fungi and microalgae occurs, resulting in microalgae cells incorporated into the fungal hyphae mesh. This synergy may have led to the obtention of an enzymatic extract with high resilience capacity in peroxidase activity, which can be seen in Fig. 1, where the interaction between the enzyme and reaction medium over time is shown under constant environmental conditions.

[Fig. 1 near here]

To ensure that the evaporation or natural oxidation of the enzymatic extract did not induce false positives, controls were performed and considered in the enzymatic activity quantification. During the follow-up of the reaction, in the first $192 \mathrm{~h}$, the $\mathrm{pH}$ and ORP values were maintained without statistically significant differences. The $\mathrm{pH}$ remained between $7.3 \pm 0.1$ and $7.6 \pm 0.1$, and the ORP between $195.6 \pm$ 3.3 and $214.2 \pm 1.1 \mathrm{mV} v$ s. SHE. In turn, the enzymatic activity varied from $7801 \pm 179$ to $11 \pm 2 \mathrm{U} \mathrm{mg}^{-1}$, significantly decreasing and reaching its minimum value in $96 \mathrm{~h}$.

In the last experimental point studied ( $360 \mathrm{~h}$ ), the pH significantly dropped to $6.5 \pm 0.4$, and the redox potential increased to $262.0 \pm 20.4 \mathrm{mV} v$ s. SHE. For this experimental point, the standard error became high and, therefore, the experiment was stopped. In this sense, it is understood that after $360 \mathrm{~h}$, it is unfeasible to maintain the enzymatic reaction without providing maintenance.

The constant decrease in enzymatic activity in the first hours of reaction follows the same behavior as observed in a published study for guaiacol peroxidase extracted from rice bran ${ }^{38}$, in which in $24 \mathrm{~h}$ of reaction, the activity had already fallen more than half of the initial value. In the present study, intra and extracellular enzymatic system of the fungus can be critical in conducting the catalytic route through the quinone redox cycling mechanism. The presence of lignin and $\mathrm{Fe}^{2+}$ in class II heme peroxidases structure induces a reaction that produces hydroxyl radicals in the presence of hydrogen peroxide. The enzymatic behavior shown in Fig. 1 can thus configure an advanced bioxidative process, in 
which the cosubstrate presence generates hydroxyl radicals, which in turn can regenerate cosubstrate. Thus, the enzymatic reaction is naturally maintained, without the need of external interventions ${ }^{39}$.

The maintenance of positive ORP values during the reaction suggests that the reaction medium was receiving electrons, and the substrate was oxidized. At the end of the reaction, the increase in ORP may have been a reflection of $\mathrm{pH}$ decrease, these parameters being inversely proportional ${ }^{40}$. The change in these parameters may have triggered the enzymatic reaction instability, which had already carried out multiple quinone redox cycles.

Considering the promising results of peroxidase activity and reaction maintenance even in adverse conditions, studies were conducted to monitor the enzymatic activity of the crude extract after storage. The results of this characterization are shown in Fig. 2.

[Fig. 2 near here]

The enzymatic extract activity (initially $7801 \mathrm{U} \mathrm{mg}^{-1}$ ) remained more stable at room temperature and in the refrigerator than in the freezer. For the storage condition between $18-28^{\circ} \mathrm{C}$, there was no significant difference in activity up to the $60^{\text {th }}$ day, reaching $105 \pm 3 \%$ of residual activity. For storage at $4{ }^{\circ} \mathrm{C}$, a considerable drop was observed between 30 and 90 days ( $91 \pm 1 \%$ ), but on the $170^{\text {th }}$ day, the RA returned to the initial value. In turn, the extract maintained at $-10{ }^{\circ} \mathrm{C}$, initiated a significant and current drop of enzymatic activity after 15 days, reaching $63 \pm 1 \%$ of RA in 90 days.

From these tests, it was possible to determine that the enzymatic extract can be kept in the refrigerator for up to 170 days without sudden drops in peroxidase activity. In addition, keeping the extract at room temperature proved to be an interesting option for up to 60 days, but it still requires studies for longer periods, as on the $170^{\text {th }}$ day, a significant drop was observed. Therefore, the activity behavior after storage will be discussed in the next section.

\section{Strategies for T. koningiopsis peroxidase immobilization}

Three different strategies were selected to conduct the immobilization process of crude peroxidase extract (Free-POD), obtained in the fermentation process of Trichoderma supplemented by Chlorella spp. Two parameters were chosen to determine the immobilization efficiency: the residual activity and the discoloration potential of the brown dye solution at $100 \mathrm{mg} \mathrm{L}^{-1}$. This treatment process was selected because of its promising results in crude extract assays, the scarcity of studies on this dye, and the objective of inserting this bioproduct in the context of low-biodegradability contaminant remediation.

The immobilization strategies of this study were selected, taking into account the cost-benefit in the scenario of effluent treatment and circular economy. The strategies allowed obtaining relevant results, with an increase in specific activity of up to $589 \%$ and color removal of up to $100 \%$, as shown in Table 3 .

[Table 3 near here] 
RA values up to $100 \%$ indicate enzymatic retention in the support for the technique studied, and higher values demonstrate a positive interaction between support and enzyme. For the encapsulation method, it was possible to retain only $6 \%$ of enzyme in the POD-beads, and $22 \%$ was lost to the calcium chloride solution. When the technique was modified (ModPOD-beads), adding the POD substrate and cosubstrate to the beads to manipulate the affinity between enzyme and support, the retention was lower (3\%), as well as the activity in the solution (21\%). These results indicate that the encapsulation technique is not suitable for Trichoderma peroxidase because of the low enzymatic retention in the beads. There was also a loss of enzymatic activity in the process, since the RA balance considering beads and solution does not reach the reference value $(100 \%)$.

Two different supports were studied in the adsorption method: the commercial clay MK10, widely used in enzymatic immobilization studies, and noncommercial ornamental rock dust (OR). The choice of this alternative support was motivated by the environmental problem related to the disposal of this waste material, which is constantly generated by rock processing industries. For both supports, enzymatic activity was lost to the buffer solution, in which the contact process with peroxidase was conducted (19\% for MK10 and 15\% for OR). However, the commercial support had a greater affinity with the enzyme, with a $35 \%$ activity retention, when compared to rock dust (11\%). When making the RA balance, a loss of activity was observed in this case. However, compared to the encapsulation strategy, adsorption proved to be more promising and retained higher enzymatic activities in the supports.

The most advantageous process from the perspective of maintenance and even of increasing enzymatic activity after immobilization was by magnetic nanozymes synthesis, conducted with low-cost reagents. In this strategy, although part of the activity was lost to the solution in which the nanoparticles precipitated, the bond between POD and support favored the expression of catalytic activity. This process made it possible to obtain $21111 \mathrm{U} \mathrm{mg}^{-1}$ of specific activity in MN-POD, representing a RA of $689 \%$, and relevant potential for application in biotechnological processes due to their magnetic properties.

As in the present study, commercial horseradish peroxidase was immobilized by magnetic nanocomposites by Chang et al. ${ }^{41}$, exhibiting biochemical properties superior to those of the free enzyme, maintaining the RA in $100 \%$ and improving resistance to temperature and $\mathrm{pH}$ variations. In turn, Monteiro et al. ${ }^{42}$ investigated the immobilization of commercial Candida antarctica lipase onto magnetic nanoparticles and achieved RA values of up to $120 \%$ for a pH range between 8 and 10 . This same RA value was achieved for POD magnetic nanozymes in Sadaf et al. ${ }^{21}$ study, however for a $\mathrm{pH}$ range between 3 and 4 . Although for each nanoparticle synthesis study, different methods are used, and will give them particular biochemical characteristics, Zdarta et al. ${ }^{43}$ highlight that the presence of many functional groups in the materials used for the synthesis gives to the nanozymes a high surface area and porosity. These characteristics may justify the fixation of a large amount of enzyme in the nanoparticles and the increase in catalytic activity compared to the free enzyme.

Among the techniques studied in the present work, MN-POD showed the most significant potential for discoloration, removing $100 \%$ of the color of the dye solution in 5 hours. However, in this enzymatic 
treatment, the acidic $\mathrm{pH}$ of the post-treatment solution would require adjustment before its final disposal. For treatments with POD immobilized by encapsulation and adsorption techniques, the $\mathrm{pH}$ remained close to neutrality; however, color removals of only up to $42 \%$ were obtained.

From the data presented in Table 3, it is not possible to determine a direct relationship between RA and DP values. It is worth mentioning that blank control tests with dye solution and support, in the absence of enzyme, were conducted. However, they did not bring conclusive contributions, since the blank control results were mostly influenced by pore size and contact surface. The results of the enzymatic treatment depend on the cross-interaction between support, enzyme and dye, giving complexity to the process to be investigated in future works. Accordingly, in addition to enzymatic retention, the immobilization process becomes relevant to provide a combined action between support and substrate that enhances the catalytic reaction. In addition to the enzymatic activity retention, the immobilization process must provide the possibility of reusing and storing the enzyme, maintaining catalytic efficiency. In this sense, MN-POD was applied to the second batch brown dye treatment, in which $94 \%$ of discoloration was obtained in 5 hours, maintaining the same conditions as the first batch.

In the storage test, MK10-POD, OR-POD, and MN-POD samples were stored at room temperature protected from direct sunlight, and their activity was measured after 2.5 months of the immobilization process. Comparing to free-POD, the MK10-POD, OR-POD, and MN-POD remained with residual activities of 193\%, $3 \%$, and $10637 \%$, respectively, after the storage period. Additionally, MN-POD activity was verified after about 8 months, and it has $9238 \%$ of RA.

The data in Table 3 reveal that OR-POD lost enzymatic activity after storage, while MK10-POD and MNPOD increased it. For all samples, the specific activity of the immobilized enzyme remained higher than in free form. The same behavior of activity increase after storage was observed for the crude extract. This phenomenon can be attributed to changes in the biochemical conformation of the protein or to an increase in specificity with the substrate, which is already reported in the literature for enzymes submitted to upstream processes, such as concentration and enzymatic purification ${ }^{8}$.

The MN-POD sample stored for about 8 months, with $283256 \mathrm{U} \mathrm{mg}^{-1}$, was subjected to 10 cycles of recovery and reinsertion in a reaction medium to monitor the residual activity behavior. In cycles 2 and 3 , a statistically significant decay in RA was observed, arriving at the end of cycle 3 with 37\%. From cycles 4 to 10 , there was no considerable decay in RA. At the end of the experiment, the MN-POD had $13546 \mathrm{U} \mathrm{mg}^{-}$ 1 of specific activity, corresponding to $5 \%$ of RA. Both activity and degradation efficiency decay are expected in reusability assays, considering that the enzyme active site and the support pore voids are filled over cycles ${ }^{9,44}$.

In this study, the enzymatic activity improvement was possible using simple immobilization techniques and interesting cost-benefit, factors of great relevance in industrial applications. In addition, the bioproduct storage under mild conditions, dispensing chemical supplement addition, or freeze-drying 
processes, are advantages to its insertion in the enzyme market for industrial applications, which is in constant expansion according to the latest Global Industry Analysts report ${ }^{4}$.

\section{Support and immobilized peroxidase characterization}

OR-POD, MN-POD, and MK10-POD samples were submitted to characterization to understand the interactions between enzyme and support. In addition, support samples without enzyme were also characterized.

The FTIR and XRD graphs are presented in Fig. 3 and, from a first examination, it is possible to observe the similarities when comparing the spectrum of the support and support with enzyme; the transmittance peaks are in the same wavenumber range in FTIR analysis, as well as the intensity peaks in the same $2 q$ values in XRD patterns.

These findings indicate that the enzyme-support interaction did not modify the characteristic chemical bonds or the structural arrangement of the support material atoms during the immobilization processes. This aspect is positively relevant considering that immobilization aims to maintain both enzymatic and material properties. In the current work, this objective was achieved, and the immobilization maintained peroxidase catalytic activity without affecting the physical-chemical characteristics of the materials.

[Fig. 3 near here]

Another relevant observation is the similarities, for the two analyses, of the peak behavior for the adsorption methods (samples OR-POD, OR, MK10-POD, and MK10), indicating that ornamental rock dust is very similar to the commercial and widely used clay MK10. The FTIR spectra of these samples show weak peaks between 820 and $947 \mathrm{~cm}^{-1}$ (Fig. 3a), corresponding to $\mathrm{Al}-\mathrm{Al}-\mathrm{OH}, \mathrm{Al}-\mathrm{Fe}-\mathrm{OH}$ and $\mathrm{Al}-\mathrm{Mg}-\mathrm{OH}$ deformation, and $\mathrm{Si}-\mathrm{O}$ stretching mode. The absence of peaks around $1000 \mathrm{~cm}^{-1}$ indicates no water content in the samples ${ }^{45}$.

For MN and MN-POD samples, small intensity peaks were observed at 935, 1059, and $1144 \mathrm{~cm}^{-1}$, suggesting the presence of a significant amount of specifically adsorbed sulfate groups. These can occupy external and internal surfaces (sulfated goethite), and the amount of these groups is related to the acidic $\mathrm{pH}$. The peak at $1591 \mathrm{~cm}^{-1}$ indicates $\mathrm{H}_{2} \mathrm{O}$ bending vibrations ${ }^{46}$.

In XRD analysis of magnetic nanoparticles, the peaks indicated in Fig. 3b, between 27 and $50^{\circ}$, confirm goethite presence as a single phase, characteristic of superparamagnetic particles ${ }^{47}$. Also, characteristic peaks corresponding to planes of $\mathrm{Fe}_{3} \mathrm{O}_{4}$ and $\mathrm{MgO}$ crystals were observed, whose low intensity is due to the small size of the synthesized particles ${ }^{48}$.

The amorphous characteristic of the MN and MN-POD samples is another positive relevant finding from the XRD analysis. It is beneficial for many applications due to the superior catalytic activity, superparamagnetic behavior, and large surface area compared with crystalline structures ${ }^{49}$. 
Experimental conditions are relevant in amorphous $\mathrm{Fe}_{3} \mathrm{O}_{4}$ synthesis, especially regarding particle size and structure homogeneity ${ }^{50}$. In this sense, the method we used can be considered adequate for obtaining excellent magnetic nanoparticles.

From the XRD patterns in Fig. 3b, it is possible to verify very similar crystalline structures of OR-POD, OR, MK10-POD, and MK10. The $2 q$ values variation between samples does not exceed 0.5 degrees, but there are some differences in intensity. The main highlight is the occurrence of an intense peak at $60.2^{\circ}$ for OR, confirming that this material has $\mathrm{SiO}_{2}$, as expected, since it is the primary mineral of this material. Small intense peaks associated with $\mathrm{SiO}_{2}$ are also clearly observed at 26.7 and $27.5^{\circ}$, both for OR and MK10. The remaining low intense peaks in Fig. $3 \mathrm{~b}$ are natural mineral signatures and were expected for these materials ${ }^{45}$.

\section{Toxicological assessment of enzymatic treatments}

The test organism selected was A. cepa, in which disorders in cell division can be counted and compared using the mitotic index. With a negative control as a standard (cells exposed to tap water), higher or lower mitotic index (MI) values indicate disorders in the mitosis process, as shown in Table 4.

According to Fiskesjö ${ }^{22}$, one of the precursors of this test, the meristematic onion cells study, is indicated for environmental monitoring, presenting advantages such as low cost, easy execution, and possibilities of microscopic research, being possible to evaluate the chromosomal damage caused by an aqueous matrix and disorders in cell division.

[Table 4 near here]

By qualitative observations on slides, it was possible to detect chromosomal aberrations caused by enzymatic treatments. In Fig. 4, these damages are indicated to emphasize them in some of the treatments. The presence of micronuclei in free-POD treatment is one of the main genotoxic highlights, indicating that the crude enzymatic extract can induce uncontrolled cell division and possibly tumor formation ${ }^{51}$. In contrast, chromosomal aberrations were not observed for the other treatments, indicating that enzymatic immobilization is relevant to eliminate genotoxic effects. However, for all assays, disorders in the mitosis process were quantified, as shown in Table 4.

[Fig. 4 near here]

In the MN-POD assay, for which complete discoloration was achieved, the acceleration phenomenon of cell division was quantified, increasing by 5.0 times compared with the negative control. When the sample was diluted at 1:8, a delay in cell division occurred ( 0.2 times), being possible to verify this by $\mathrm{MI}$ values (Table 4) and visual comparison between images (a), (c), and (d) of Fig. 4. As in negative control (tap water), for the enzymatic-treated samples, the cells were predominantly in the prophase phase, i.e, the first stage of cell division. In turn, in the dye solution before treatment, all the division phases were visualized, although the MI value was only 1.1 times greater than the negative control. 
The findings regarding the cell division phases are relevant since cells in metaphase and anaphase are more susceptible to chromosomal changes and DNA abnormalities ${ }^{52}$. In this sense, cytotoxic and genotoxic analyses provide complementary results since mitotic indexes close to the negative control value do not guarantee the absence of chromosomal aberrations. According to Fiskesjö ${ }^{22}$, toxicological assessment can provide a diagnosis of possible behaviors of the test organism when exposed to treatments, but it is a result of multiple factors combined. For example, the author found a relationship between the $\mathrm{pH}$ of the solution and toxicological effects; however, it was not possible to find this direct relationship between disorder in cell division and $\mathrm{pH}$ in our work.

Miranda-Mandujano et al. ${ }^{28}$ and Feng et al. ${ }^{53}$ attributed the increase in toxic effects after enzymatic reaction to the formation of transformation products, during the catalytic route. It is believed that in our study, these products with distinct toxic effects may have been formed after enzymatic treatment because of the disorders caused by cell division. These disorders are possibly related to the different enzymatic conformations obtained by the immobilization strategies, considering that other cytotoxic behaviors occurred between tests, even with dye concentration and operating conditions being equal.

The samples dilution before exposure to $A$. cepa cells resulted in a change in cell division behavior, as indicated by the results in Table 4. It is understood that the search for a dilution factor in the context of the treatment proposed in this work can be one of the strategies for reaching MI values closer to the negative control. It is worth mentioning that the degradation of different compounds by the enzymatic route presents different responses from the toxicological point of view. Therefore, it is relevant that treatments inserted in other contexts are deeply analyzed considering multiple aspects.

\section{Conclusions}

The search for solutions to problems caused by human activities has become increasingly necessary. This work discusses proposals for producing and immobilizing peroxidase using low-cost processes and reagents and providing a bioproduct with oxidative potential for pollutant remediation in aqueous matrices.

The enzymatic extract was produced by submerged fermentation of the fungus $T$. koningiopsis, supplemented exclusively by microalgae cultivated in swine wastewater digestate, placing it in the context of circular economy. The extract showed potential for insertion in advanced bioxidative reactions due to the presence of guaiacol peroxidase with good stability when subjected to extreme reaction conditions. The bioproduct presented an adequate behavior, expressing specific activity of up to $7801 \mathrm{U}$ $\mathrm{mg}^{-1}$ in the free form and $21111 \mathrm{U} \mathrm{mg}^{-1}$ when immobilized. It is worth highlighting the promising results in storage tests at room temperature for up to 8 months, mantaining the catalytic efficiency over time.

The T. koningiopsis peroxidase and the immobilization processes studied in the present work were also promising, considering its potential for synthetic dye discoloration, removing $100 \%$ of the color in 5 hours, and $94 \%$ in the enzyme reuse test, even with drop in the specific activity. The technique of magnetic 
nanozyme synthesis proved to be the most promising both from the point of view of discoloration potential and the maintenance of residual activity. Nanozymes also have the advantage of direct recovery with the aid of a magnetic field, enabling reuse for multiples catalytic cycles. Howevert, free-POD showed cytotoxic and genotoxic effects in assays with the test organism A. cepa, while immobilized POD did not show genotoxicity.

\section{Declarations}

Competing interests

The authors declare that they have no conflict of interest.

Ethics approval and consent to participate

Not applicable.

Consent for publication

All authors agreed with this publication.

Availability of data and materials

The datasets generated for this study are available on request to the corresponding author.

\section{Authors' contributions}

N Klanovicz: Conceptualization, investigation, data curation, formal analysis, writing - original draft. FS Stefanski: Conceptualization, investigation, data curation, formal analysis, writing - original draft. AF Camargo: Conceptualization, investigation, data curation, formal analysis.

W Michelon: Conceptualization, investigation, data curation, formal analysis. ACSC Teixeira: Supervision, project administration, funding acquisition, writing - review \& editing. H Treichel: Supervision, project administration, funding acquisition, writing - review \& editing.

\section{ACKNOWLEDGEMENTS}

The authors are grateful to the following Brazilian research agencies: Fundação de Amparo à Pesquisa do Estado do Rio Grande do Sul - FAPERGS, Coordenação de Aperfeiçoamento de Pessoal de Nível Superior - Brasil (CAPES), and Conselho Nacional de Desenvolvimento Científico e Tecnológico - CNPq; to the research group at Laboratório de Experimentação e Análises Ambientais (Embrapa Suínos e Aves Concórdia, Brazil); and to Dra. Solange Sakata, from Centro de Tecnologia das Radiações (Instituto de Pesquisas Energéticas e Nucleares - São Paulo, Brazil).

\section{References}


1. Ali L, Algaithi R, Habib HM, Souka U, Rauf MA, Ashraf S. Soybean peroxidase-mediated degradation of an azo dye - a detailed mechanistic study. BMC Biochem 14(1):35. (2013) DOI: 10.1186/1471-2091-14-35

2. Singh MP, Vishwakarma SK, Srivastava AK. Bioremediation of Direct Blue 14 and Extracellular Ligninolytic Enzyme Production by White Rot Fungi: Pleurotus Spp. Biomed Res Int 2013:180156. (2013). DOI: $10.1155 / 2013 / 180156$

3. Saroj S, Kumar K, Pareek N, Prasad R, Singh RP. Biodegradation of azo dyes Acid Red 183, Direct Blue 15 and Direct Red 75 by the isolate Penicillium oxalicum SAR-3. Chemosphere 107:240-248. (2014). DOI: 10.1016/j.chemosphere.2013.12.049

4. Research and Markets, Industrial Enzymes - Global Market Trajectory \& Analytics, Report ID 338655. Global Industry Analysts, 402 p (2021).

5. Jun LY, Yon LS, Mubarak NM, Bing CH, Pan S, Danquah MK, et al. An overview of immobilized enzyme technologies for dye and phenolic removal from wastewater. J Environ Chem Eng 7(2):102961. (2019). DOI: 10.1016/j.jece.2019.102961

6. Morsi R, Bilal M, Iqbal HMN, Ashraf SS. Laccases and peroxidases: The smart, greener and futuristic biocatalytic tools to mitigate recalcitrant emerging pollutants. Sci Total Environ 714:136572. (2020). DOI: 10.1016/j.scitotenv.2020.136572

7. Viancelli A, Michelon W, Rogovski P, Cadamuro RD, de Souza EB, Fongaro G, et al. A review on alternative bioprocesses for removal of emerging contaminants. Bioprocess Biosyst Eng. 43:2117-29. (2020). DOI: 10.1007/s00449-020-02410-9

8. Abedi D, Zhang L, Pyne M, Chou CP. Enzyme Biocatalysis, in Comprehensive Biotechnology, ed by Moo-Young M. Elsevier, pp 15-24 (2011). DOI: 10.1016/B978-0-444-64046-8.00003-3

9. Shakerian F, Zhao J, Li S-P. Recent development in the application of immobilized oxidative enzymes for bioremediation of hazardous micropollutants - A review. Chemosphere 239:124716. (2020). DOI: 10.1016/j.chemosphere.2019.124716

10. Bilal M, Rasheed T, Zhao Y, Iqbal HMN, Cui J. "Smart" chemistry and its application in peroxidase immobilization using different support materials. Int J Biol Macromol 119:278-290. (2018). DOI: 10.1016/j.ijbiomac.2018.07.134

11. Anawar HM, Ahmed G. Combined electrochemical-advanced oxidation and enzymatic process for treatment of wastewater containing emerging organic contaminants, in Emerging and Nanomaterial Contaminants in Wastewater, ed by Mishra AK, Anawar HM, Drouiche N. Elsevier, pp 277-307 (2019). DOI: 10.1016/B978-0-12-814673-6.00010-3 
12. Reichert Júnior FW, Scariot MA, Forte CT, Pandolfi L, Dil JM, Weirich S, et al. New perspectives for weeds control using autochthonous fungi with selective bioherbicide potential. Heliyon 5(5): 01676. (2019). DOI: 10.1016/j.heliyon.2019.e01676

13. Michelon W, Da Silva MLB, Mezzari MP, Pirolli M, Prandini JM, Soares HM. Effects of Nitrogen and Phosphorus on Biochemical Composition of Microalgae Polyculture Harvested from Phycoremediation of Piggery Wastewater Digestate. Appl Biochem Biotechnol 178(7):1407-1419. (2016). DOI:

$10.1007 / \mathrm{s} 12010-015-1955-\mathrm{x}$

14. Stefanski FS, Camargo AF, Scapini T, Bonatto C, Venturin B, Weirich SN, et al. Potential Use of Biological Herbicides in a Circular Economy Context: A Sustainable Approach. Front Sustain Food Syst 4:521102. (2020). DOI: 10.3389/fsufs.2020.521102

15. Garda-Buffon J, Kupski L, Badiale-Furlong E. Deoxynivalenol (DON) degradation and peroxidase enzyme activity in submerged fermentation. Food Sci Techno/ 31(1):198-203. (2011). DOI:

10.1590/S0101-20612011000100030

16. Hou H, Zhou J, Wang J, Du C, Yan B. Enhancement of laccase production by Pleurotus ostreatus and its use for the decolorization of anthraquinone dye. Process Biochem 39(11):1415-149. (2004). DOI: 10.1016/S0032-9592(03)00267-X

17. Bradford M. A Rapid and Sensitive Method for the Quantitation of Microgram Quantities of Protein Utilizing the Principle of Protein-Dye Binding. Anal Biochem 72(1-2):248-254. (1976), DOI: 10.1006/abio.1976.9999

18. Klanovicz N, Camargo AF, Stefanski FS, Zanivan J, Scapini T, Pollon R, et al. Advanced oxidation processes applied for color removal of textile effluent using a home-made peroxidase from rice bran. Bioprocess Biosyst Eng 43(2):261-272. (2020). DOI: 10.1007/s00449-019-02222-6

19. Rezvani F, Azargoshasb H, Jamialahmadi O, Hashemi-Najafabadi S, Mousavi SM, Shojaosadati SA. Experimental study and CFD simulation of phenol removal by immobilization of soybean seed coat in a packed-bed bioreactor. Biochem Eng J 101:32-43. (2015). DOI: 10.1016/j.bej.2015.04.019

20. Coghetto CC, Scherer RP, Silva MF, Golunski S, Pergher SBC, de Oliveira D, et al. Natural montmorillonite as support for the immobilization of inulinase from Kluyveromyces marxianus NRRL Y7571. Biocatal Agric Biotechnol 1(4):284-289. (2012). DOI: 10.1016/j.bcab.2012.06.005

21. Sadaf A, Ahmad R, Ghorbal A, Elfalleh W, Khare SK. Synthesis of cost-effective magnetic nanobiocomposites mimicking peroxidase activity for remediation of dyes. Environ Sci Pollut Res 27(22):27211-2720. (2020). DOI: 10.1007/s11356-019-05270-3

22. Fiskesjö G. The Allium test as a standard in environmental monitoring. Hereditas 102(1):99-112. (1985). DOI: 10.1111/j.1601-5223.1985.tb00471.x 
23. Skoog DA, West DM, Holler J, Crouch SR. Fundamentals of Analytical Chemistry. Cengage Learning, $1072 \mathrm{p}$ (2013).

24. Brown TE, LeMay HE, Bursten BE, Murphy C, Woodward P. Chemistry: The Central Science in SI Units. Pearson, 1248 p (2017).

25. Rodrigues MI, lemma AF. Experimental design and process optimization. CRC Press, $336 \mathrm{p}$ (2014).

26. Dawkar VV, Jadhav UU, Telke AA, Govindwar SP. Peroxidase from Bacillus sp. VUS and its role in the decolorization of textile dyes. Biotechnol Bioprocess Eng 14(3):361-368. (2009). DOI: $10.1007 /$ s12257-008-0242-x

27. Hamid M, Khalil-ur-Rehman. Potential applications of peroxidases. Food Chem 115(4):1177-1186. (2009). DOI: 10.1016/j.foodchem.2009.02.035

28. Miranda-Mandujano E, Moeller-Chávez G, Villegas-Rosas O, Buitrón G, Garzón-Zúñiga M. Decolourization of Direct Blue 2 by peroxidases obtained from an industrial soybean waste. Water SA 44: (2 April). (2018). DOI: 10.4314/wsa.v44i2.06

29. Haddaji D, Bousselmi L, Saadani O, Nouairi I, Ghrabi-Gammar Z. Enzymatic degradation of azo dyes using three macrophyte species: Arundo donax, Typha angustifolia and Phragmites australis. Desalin Water Treat 1-10. (2014). DOI: 10.1080/19443994.2014.884475

30. Shaffiqu TS, Roy JJ, Nair RA, Abraham TE. Degradation of Textile Dyes Mediated by Plant Peroxidases. Appl Biochem Biotechnol 102-103(1-6):315-326. (2002). DOI: 10.1385/ABAB:102-103:1$6: 315$

31. Shrivastava R, Christian V, Vyas BRM. Enzymatic decolorization of sulfonphthalein dyes. Enzyme Microb Technol 36(2-3):333-337. (2005). DOI: 10.1016/j.enzmictec.2004.09.004

32. Soares GMB, Pessoa de Amorim MT, Costa-Ferreira M. Use of laccase together with redox mediators to decolourize Remazol Brilliant Blue R. J Biotechnol 89(2-3):123-129. (2001). DOI: 10.1016/S0168-1656(01)00302-9

33. Mäkelä MR, Hildén KS, Kuuskeri J. Fungal Lignin-Modifying Peroxidases and $\mathrm{H}_{2} \mathrm{O}_{2}$-Producing Enzymes, in Reference Module in Life Sciences, ed by Zaragoza O, Casadevall A. Elsevier, pp 247-259 (2020). DOI: 10.1016/B978-0-12-809633-8.21127-8

34. Azmi MA, Yusof MT, Zunita Z, Hassim HA. Enhancing the utilization of oil palm fronds as livestock feed using biological pre-treatment method. IOP Conf Ser Earth Environ Sci 230:012077. (2019). DOI: 10.1088/1755-1315/230/1/012077

35. Nelson DL, Cox MM. Lehninger Principles of Biochemistry. W. H. Freeman, 1340 p (2012). 
36. Baiyee B, Ito S, Sunpapao A. Trichoderma asperellum T1 mediated antifungal activity and induced defense response against leaf spot fungi in lettuce (Lactuca sativa L.). Physiol Mol Plant Pathol 106:96-101. (2019). DOI: 10.1016/j.pmpp.2018.12.009

37. Bordin ER, Frumi Camargo A, Rossetto V, Scapini T, Modkovski TA, Weirich S, et al. Non-Toxic Bioherbicides Obtained from Trichoderma koningiopsis Can Be Applied to the Control of Weeds in Agriculture Crops. Ind Biotechno/ 14(3):157-163. (2018). DOI: 10.1089/ind.2018.0007

38. Klanovicz N, Warken A, Paliga L, Camargo AF, Scapini T, Buffon JG, et al. One-step procedure for peroxidase concentration, dye separation, and color removal by aqueous two-phase system. Environ Sci Pollut Res 28(8):9097-9106. (2021). DOI: 10.1007/s11356-020-11412-9

39. Vasiliadou IA, Molina R, Pariente MI, Christoforidis KC, Martinez F, Melero JA. Understanding the role of mediators in the efficiency of advanced oxidation processes using white-rot fungi. Chem Eng $J$ 359:1427-1435. (2019). DOI: 10.1016/j.cej.2018.11.035

40. Battistuzzi G, Bellei M, Bortolotti CA, Sola M. Redox properties of heme peroxidases. Arch Biochem Biophys 500(1):21-36. (2010). DOI: 10.1016/j.abb.2010.03.002

41. Chang Q, Jiang G, Tang H, Li N, Huang J, Wu L. Enzymatic removal of chlorophenols using horseradish peroxidase immobilized on superparamagnetic $\mathrm{Fe}_{3} \mathrm{O}_{4} /$ graphene oxide nanocomposite. Chinese J Cata/ 36(7):961-968. (2015). DOI: 10.1016/S1872-2067(15)60856-7

42. Monteiro RRC, Lima PJM, Pinheiro BB, Freire TM, Dutra LMU, Fechine PBA, et al. Immobilization of Lipase A from Candida antarctica onto Chitosan-Coated Magnetic Nanoparticles. Int J Mol Sci 20:4018. (2019). DOI: 10.3390/ijms20164018

43. Zdarta J, Meyer AS, Jesionowski T, Pinelo M. Developments in support materials for immobilization of oxidoreductases: A comprehensive review. Adv Colloid Interface Sci 258:1-20. (2018). DOI: 10.1016/j.cis.2018.07.004

44. Sastre DE, Reis EA, Marques Netto CGC. Strategies to rationalize enzyme immobilization procedures, in Methods in Enzymology, ed by Kumar CV. Elsevier, pp 81-110 (2020) DOI: 10.1016/bs.mie.2019.09.003

45. Ahmed A, Chaker Y, Belarbi EH, Abbas O, Chotard JN, Abassi HB, et al. XRD and ATR/FTIR investigations of various montmorillonite clays modified by monocationic and dicationic imidazolium ionic liquids. J Mol Struct 1173:653-664. (2018). DOI: 10.1016/j.molstruc.2018.07.039

46. Gotić M, Musić SM. FT-IR and FE SEM investigation of iron oxides precipitated from $\mathrm{FeSO}_{4}$ solutions. J Mol Struct 834-836:445-453. (2007). DOI: 10.1016/j.molstruc.2006.10.059 
47. Gotić M, Musić S, Popović S, Sekovanić L. Investigation of Factors Influencing the Precipitation of Iron Oxides from Fe(II) Containing Solutions. Croat Chem Acta 81(4):569-578. (2008).

48. Beyki MH, Bayat M, Shemirani F. Fabrication of core-shell structured magnetic nanocellulose base polymeric ionic liquid for effective biosorption of Congo red dye. Bioresour Techno/ 218:326-234. (2016). DOI: 10.1016/j.biortech.2016.06.069

49. Machala L, Zboril R, Gedanken A. Amorphous Iron(III) Oxide - A Review. J Phys Chem B 111(16):4003-4018. (2007). DOI: 10.1021/jp064992s

50. Jolivet JP, Tronc E, Vayssieres L. Formation of Magnetic Spinel Iron Oxide in Solution, in Nanophase Materials, ed by Hadjipanayis GC, Siegel RW. Springer Netherlands, pp 45-48 (1994). DOI: 10.1007/978-94-011-1076-1_5

51. Fernandes TCC, Mazzeo DEC, Marin-Morales MA. Mechanism of micronuclei formation in polyploidizated cells of Allium cepa exposed to trifluralin herbicide. Pestic Biochem Physiol 88(3):252-259. (2007). DOI: 10.1016/j.pestbp.2006.12.003

52. Monarca S, Feretti D, Collivignarelli C, Guzzella L, Zerbini I, Bertanza G, et al. The influence of different disinfectants on mutagenicity and toxicity of urban wastewater. Water Res 34(17):4261-4269. (2000). DOI: 10.1016/S0043-1354(00)00192-5

53. Feng S, Hao Ngo H, Guo W, Woong Chang S, Duc Nguyen D, Cheng D, et al. Roles and applications of enzymes for resistant pollutants removal in wastewater treatment. Bioresour Techno/ 335:125278. (2021). DOI: 10.1016/j.biortech.2021.125278

\section{Tables}

Table 1 Strategies prospected to immobilize T. koningiopsis peroxidase. 


\begin{tabular}{c|c|c|c}
\hline Immobilization strategy & Support material & Acronym & \multirow{2}{*}{ Reference } \\
\hline Encapsulation & Ca-alginate beads & POD-beads & \multirow{2}{*}{ Rezvani et al. ${ }^{19}$} \\
\cline { 3 - 3 } & & ModPOD-beads & \\
\hline Adsorption & K10-montmorillonite & MK10-POD & \multirow{2}{*}{${\text { Coghetto et al. }{ }^{20}}^{\text {Mn }}$} \\
\cline { 2 - 3 } & Ornamental rock dust & OR-POD & \\
\hline Magnetic nanozymes & Urea-NaOH & MN-POD & \multirow{2}{*}{ Sadaf et al. ${ }^{21}$} \\
\hline
\end{tabular}

Table 2. Analysis of enzymatic treatment of synthetic dyes after five hours of reaction. Note: Means followed by equal letters indicate that the samples do not differ by Tukey test at $95 \%$ confidence level.

\begin{tabular}{c|cccc}
\hline \multirow{2}{*}{ Enzymatic amount (U) } & \multicolumn{4}{|c}{ Discoloration potential (\%) } \\
\cline { 2 - 4 } & \multicolumn{3}{|c}{ Red dye Blue dye Yellow dyeBrown dye } \\
\hline 3833 & $3^{\mathrm{a}}$ & $0^{\mathrm{a}}$ & $3^{\mathrm{a}}$ & $54^{\mathrm{b}}$ \\
\hline 7667 & $3^{\mathrm{a}}$ & $22^{\mathrm{c}}$ & $4^{\mathrm{a}}$ & $46^{\mathrm{d}}$ \\
\hline
\end{tabular}

Table 3 Immobilization of T. koningiopsis POD and results of residual activity (RA) and discoloration potential (DP) for brown dye. 


\begin{tabular}{c|c|cc}
\hline Technique acronym & RA (\%) & \multicolumn{2}{|l}{ Treatment results } \\
\cline { 3 - 4 } & & DP (\%) & Final pH \\
\hline Free-POD $^{\dagger}$ & 100 & 20 & 7.6 \\
\hline Control $^{*}$ & - & 11 & 7.8 \\
\hline POD-beads & 6 & 36 & 6.0 \\
\hline ModPOD-beads & 3 & 36 & 5.9 \\
\hline MK10-POD & 35 & 8 & 7.5 \\
\hline OR-POD & 11 & 42 & 7.6 \\
\hline MN-POD & 689 & 100 & 2.4 \\
\hline
\end{tabular}

${ }^{\dagger}$ Specific activity $=3066 \mathrm{U} \mathrm{mg}^{-1}$; * Dye solution $\left(100 \mathrm{mg} \mathrm{L}^{-1}\right)$ in the presence of $40 \mathrm{mg} \mathrm{L}^{-1}$ of hydrogen peroxide $35 \%$.

Table 4 Disorders in cell division of $A$. cepa after being exposed for $48 \mathrm{~h}$ to enzymatically treated dye solutions. 


\begin{tabular}{|c|c|c|c|}
\hline \multirow[t]{2}{*}{ Treatment assay } & \multicolumn{2}{|c|}{ Solution parameters } & \multirow[t]{2}{*}{ MI (\%) } \\
\hline & DP (\%) & $\mathrm{pH}$ & \\
\hline Negative control $^{\dagger}$ & - & $\sim 7.0$ & 18 \\
\hline Crude dye solution & 0 & 8.3 & 19 \\
\hline Free-POD & 20 & 7.6 & 8 and $7^{*}$ \\
\hline ModPOD-beads & 36 & 5.9 & 65 and $22^{*}$ \\
\hline MK10-POD & 8 & 7.5 & 29 and $10^{*}$ \\
\hline OR-POD & 42 & 7.6 & $7^{*}$ \\
\hline MN-POD & 100 & 2.4 & 89 and $3^{*}$ \\
\hline
\end{tabular}

${ }^{\dagger}$ Tap water; * Enzymatically treated dye solution diluted at 1:8.

Figures 




Figure 1

Enzymatic activity of T. koningiopsis over reaction time at pH 5.5 and $25^{\circ} \mathrm{C}$. Note: Equal letters indicate that the samples do not differ by the Tukey test at $95 \%$ confidence level. SE: standard error. 


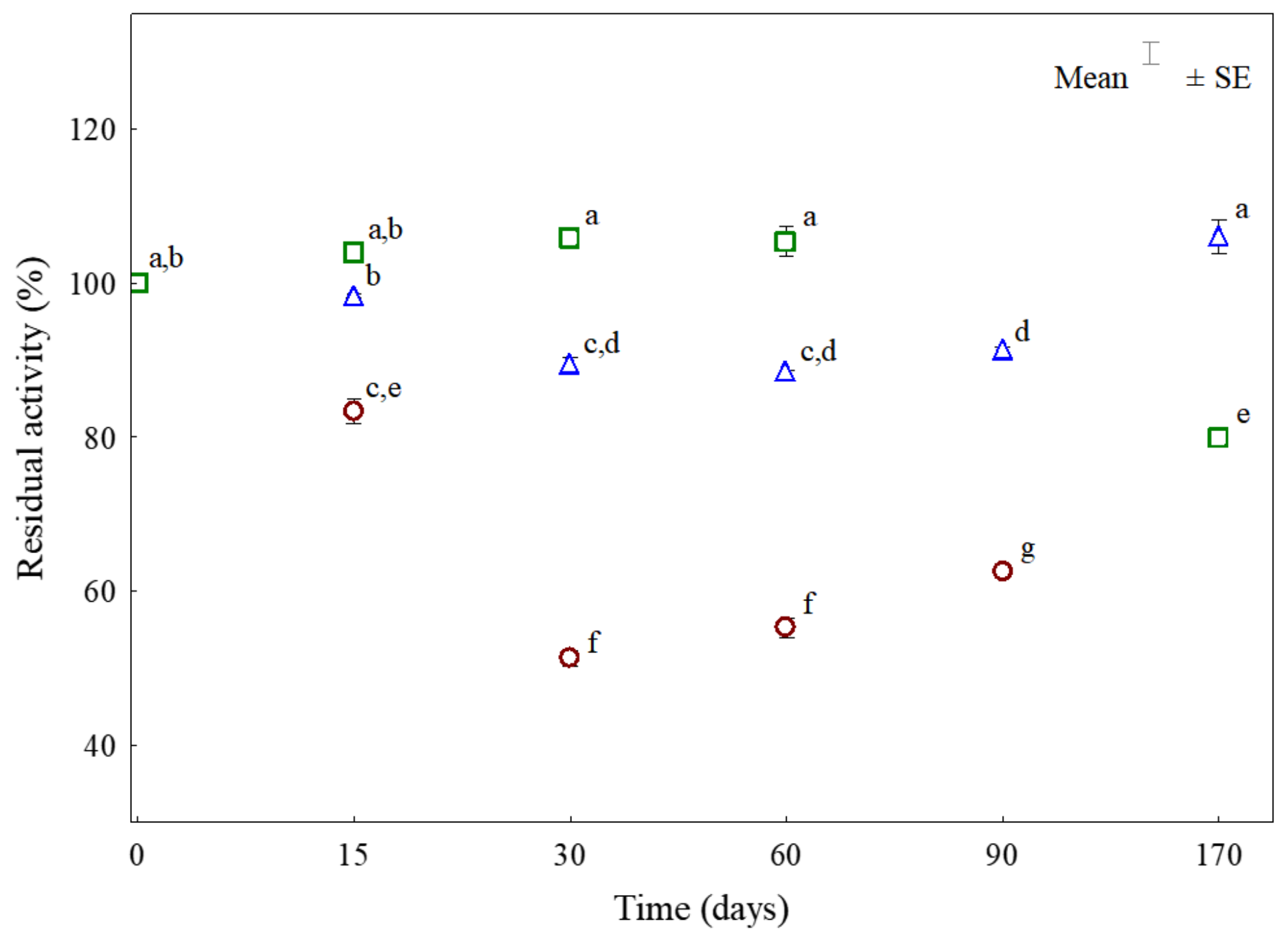

Figure 2

Monitoring free peroxidase activity stored in room temperature in the range $18-28{ }^{\circ} \mathrm{C}(\square)$, refrigerator at 4 ${ }^{\circ} \mathrm{C}(\triangle)$, and freezer at $-10{ }^{\circ} \mathrm{C}(\bullet)$. Note: Equal letters indicate that the samples do not differ by the Tukey test at $95 \%$ confidence level. SE: standard error. 
(a)

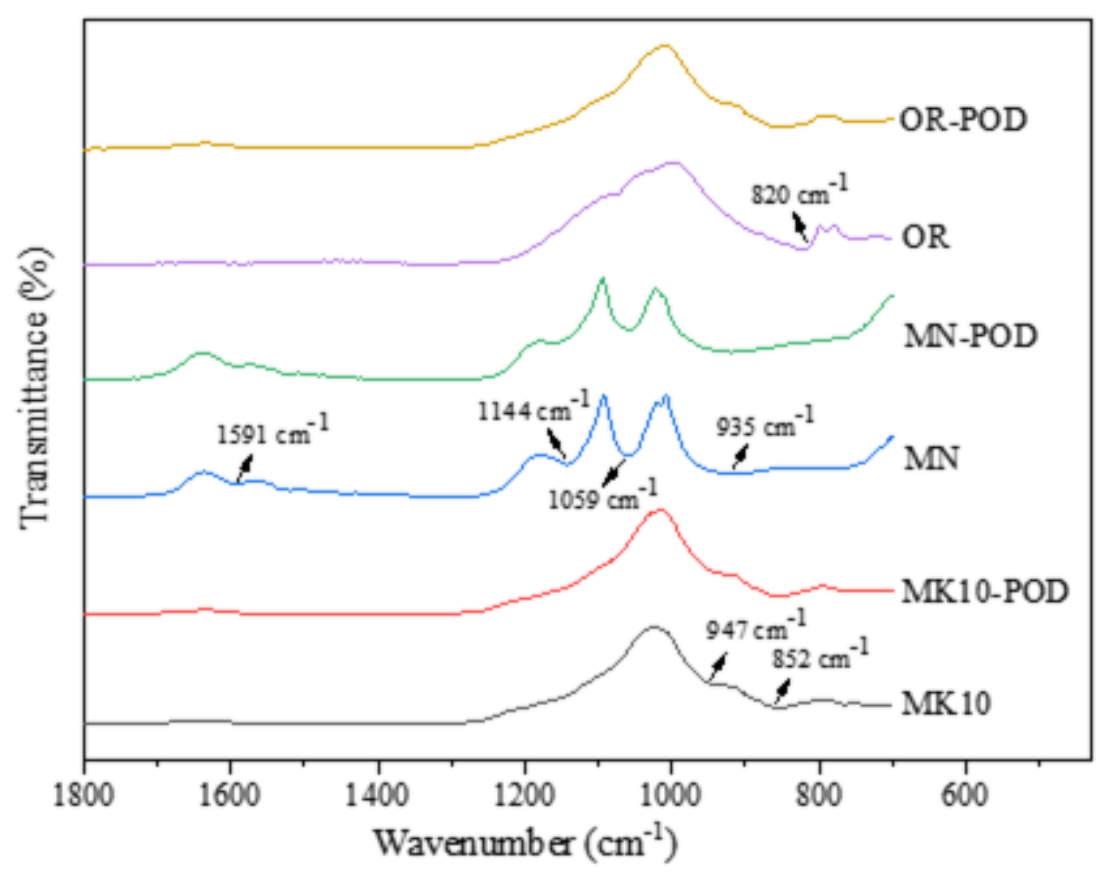

(b)

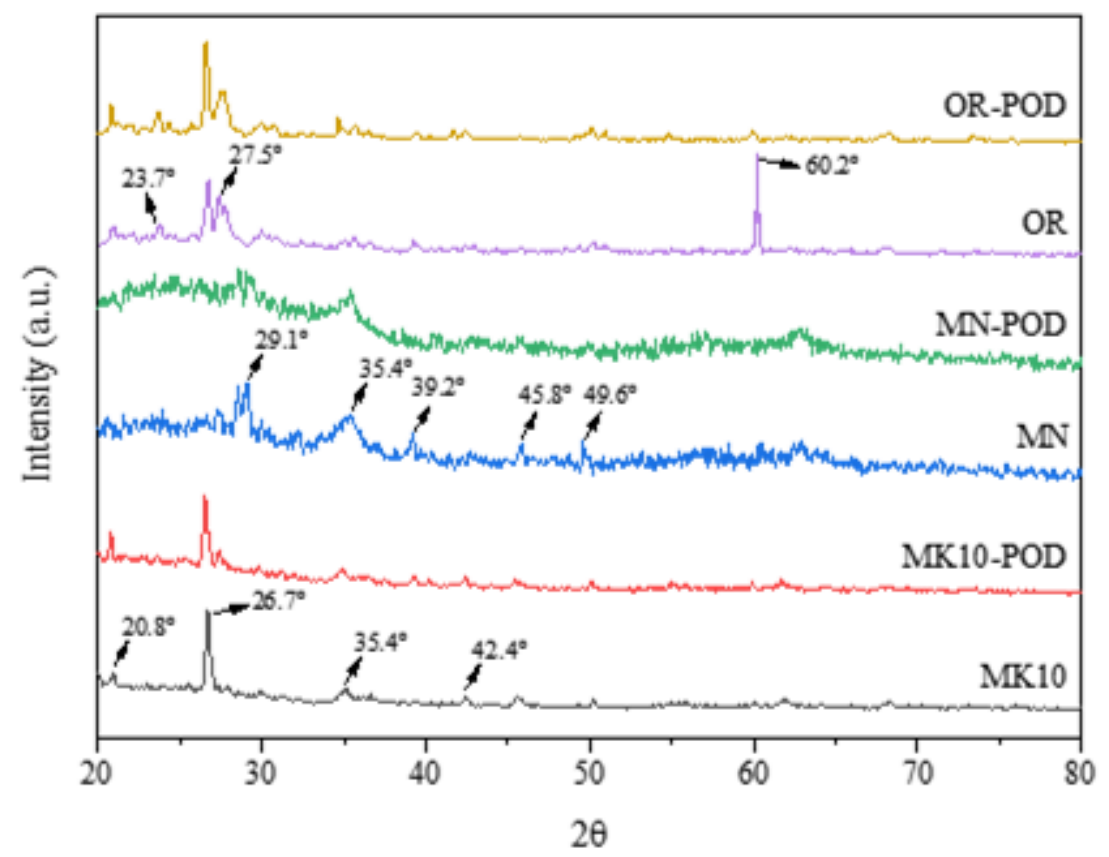

Figure 3

FTIR (a) and XRD (b) analysis of support and immobilized peroxidase. 

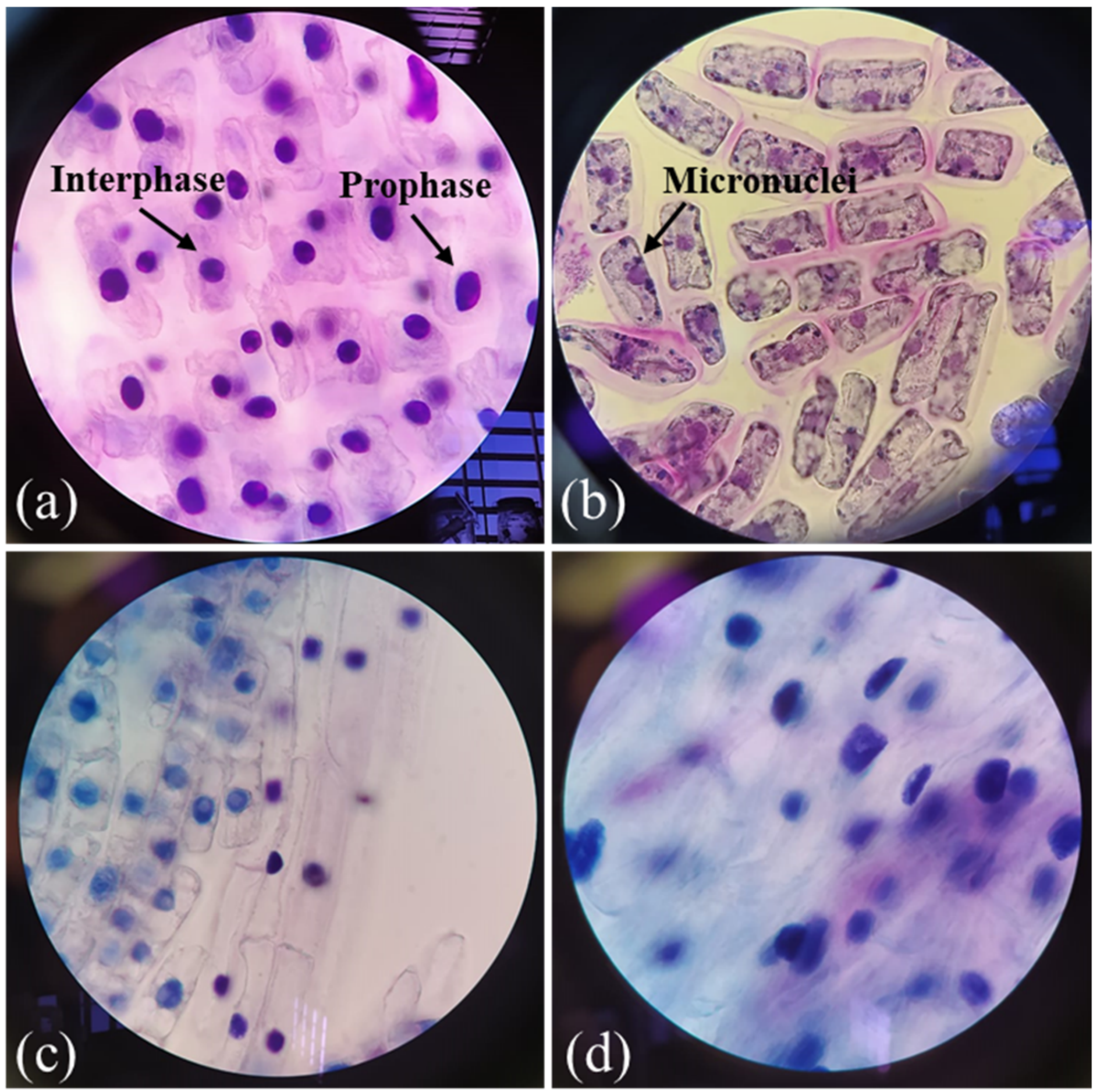

Figure 4

Microscopic observations in A. cepa cells, with 100 Í magnification lens, for (a) tap water, (b) free-POD at 1:8 dilution, (c) MN-POD, and (d) MN-POD at 1:8 dilution.

\section{Supplementary Files}

This is a list of supplementary files associated with this preprint. Click to download. 
- image.png

Page 31/31 